\title{
Treatment of Rheumatoid Arthritis with Fenoprofen: Comparison with Aspirin
}

\author{
E. C. HUSKISSON, J. A. WOJTULEWSKI, H. BERRY, JANE SCOTT, F. DUDLEY HART, \\ H. W. BALME
}

\section{Methods}

A total of 60 outpatients with classical or definite rheumatoid arthritis as defined by the American Rheumatism Association criteria were admitted to the trial. Thirty patients took part at Westminster Hospital and 30 at St. Bartholomew's Hospital.

Fenoprofen, a compound with analgesic, anti-inflammatory, and antipyretic properties in animals, has been compared with placebo in a double-blind cross-over trial in 60 patients with rheumatoid arthritis. There was a statistically highly significant reduction in pain, duration of morning stiffness, analgesic requirements, and articular index, with increase in grip strength. There was no significant reduction in joint size or temperature. In a subsequent double-blind group-comparative study fenoprofen proved to be as effective as aspirin in relieving the symptoms of rheumatoid arthritis, with strikingly fewer side effects. Almost half of the patients taking aspirin were unable to tolerate the drug in adequate dosage for six months. The remainder were able to take on average only $4 \mathrm{~g}$ daily, and at this dose almost half still complained of tinnitus and deafness.

Fenoprofen is likely to be useful for patients who cannot tolerate aspirin and other more toxic antiinflammatory drugs or whose disease is not of sufficient severity to justify their use.

\section{Introduction}

Fenoprofen, the sodium salt of DL-2-(3 phenoxyphenyl)proprionic acid, has been shown to have analgesic, anti-inflammatory, and antipyretic properties in animals (Nickander et al., 1971). In man it is rapidly absorbed from the gastrointestinal tract and reaches a peak plasma level one hour after ingestion; absorption is delayed if it is taken with food (Chernish et al., 1972). It is $99 \%$ bound to albumin but only slightly displaces warfarin from binding (Rubin et al., 1972). Fenoprofen is excreted mainly in the urine, $90 \%$ as fenoprofen-glucuronide and 4-hydroxyfenoprofen glucuronide (Rubin et al., 1972). Clinical trials have shown that single doses of fenoprofen are analgesic (Sunshine and Laska, 1971) and antipyretic (Gruber and Collins, 1972). Fenoprofen also causes less occult gastrointestinal bleeding than aspirin (Ridolfo et al., 1973).

This study was carried out to confirm the analgesic and antiinflammatory properties of fenoprofen in rheumatoid arthritis, and to compare its effectiveness and toxicity with aspirin.

St. Bartholomew's Hospital, London EC1A 7BE

E. C. HUSKISSON, M.B., M.R.C.P., Senior Registrar H. BERRY, D.M., M.R.C.P., Lecturer

JANE SCOTT, s.R.N., S.C.M., Measurement Technician

H. W. BALME, M.D., F.R.C.P., Consultant Physician

Westminster Hospital, London S.W.1

J. A. WOJTULEWSKI, M.B., M.R.C.P., Senior Research Registrar F. DUDLEY HART, M.D., F.R.C.P., Consultant Physician
FIRST TRIAL

The trial was double-blind with a cross-over design, each patient receiving fenoprofen and placebo for one week each. The drug was given in a dosage of $400 \mathrm{mg}$ four times daily on the first day of the trial, rising to $600 \mathrm{mg}$ four times daily on the second and subsequent days if symptoms were not controlled and provided that no side effects had appeared. To avoid the association of effects with identical formulations two colours of each preparation were used, pink and white. Treatment order and colour.

The trial was organized as follows: week 1, paracetamol only allowed; week 2, fenoprofen or placebo; week 3, cross-over to placebo or fenoprofen. All other anti-inflammatory drugs including aspirin were stopped before the start of the trial. Patients on gold, penicillamine, or immunosuppressive drugs were excluded. Three patients were taking $6 \mathrm{mg}$ daily or less of prednisolone or the equivalent of another preparation and had been on this dosage for at least six months.

One observer at each centre carried out all assessments using a separate form for each week and a standard explanation of the trial. The following measurements were made at the end of the second and third weeks of the trial: (1) pain, measured with a visual analogue scale; (2) duration of morning stiffness; (3) paracetamol consumption, measured by returned tablet count; (4) proximal interphalangeal joint size (Boardman and Hart, 1967); (5) articular index (Ritchie et al., 1968); (6) grip strength (total of three grips with each hand); (7) preference-patients at Westminster Hospital were asked which of the two treatment weeks they preferred; and (8) a group of 17 patients at St. Bartholomew's Hospital were studied by means of infrared thermography with the Aga thermoscan apparatus. The results were analysed by computer and a d-mac digitizing table to trace the areas of each temperature. The results were expressed as the number of degrees centigrade difference between a fixed area of the knee and an adjacent control area.

All measurements except for patient preference were analysed by Student's $t$ test applied to paired data; preference was analysed by the sign test.

\section{SECOND TRIAI}

In a second trial the same patients took part in a double-blind group-comparison study, 29 receiving fenoprofen $(2 \cdot 4 \mathrm{~g}$ daily $)$ and 31 receiving aspirin ( $6 \mathrm{~g}$ daily) in identical capsules. If symptoms were not controlled the dose was increased to a maximum of $8 \mathbf{g}$ of aspirin and $3.2 \mathrm{~g}$ of fenoprofen; if side effects occurred the dose was reduced. The preparations were supplied as identical was randomized and the trial was balanced for treatment order 
white capsules. Paracetamol was allowed freely to all patients, but no other antirheumatic medication was given except in three 1 at ients who were taking small doses of steriods (less than $5 \mathrm{mg}$ daily of prednisolone or the equivalent), in whom the dose had been unchanged for at least six months. The dose of trial medication and paracetamol was recorded and checked by returned tablet count. Patients were allocated to one or other treatment regimens according to a randomized schedule which was stratified for steroid therapy and articular index. The trial lasted for 24 weeks.

One observer at each of the two centres made all measurements, using separate recording sheets for each visit and having no previous figures for comparison. The following measures of effectiveness of treatment were made at the start of the trial, at weekly interv als for four weeks, then at monthly intervals up to the end of the 24th week of treatment: (1) pain, using a calibrated visual analogue scale; (2) duration of morning stiffness; (3) an estimate by the patient of change from the previous visit; (4) an opinion by the patient of the effectiveness of treatment; (5) limitation of movement; (6) tenderness and (7) swelling, recorded as either present or absent for a series of 30 joints; (8) grip strength; (9) proximal interphalangeal joint circumference (Boardman and Hart, 1967); and (10) time taken to walk 30 feet (9 metres).

At the same time the patients were asked if they had noticed any new symptoms which might have been related to the treatment. Side effects were recorded as slight, moderate, or severe. Full ophthalmic examination was carried out before treatment and again six months later.

The following blood tests and urine analysis were carried out before the start of treatment and at monthly intervals up to the sixth month: haemoglobin, white blood count and differential, E.S.R., platelet count, prothrombin time, serum calcium, phosphates, glucose, urea, uric acid, cholesterol, total protein, albumin, bilirubin, alkaline phosphatase and SGOT; urine pH, protein, sugar, and blood. Latex and sheep cell agglutination tests were carried out at the beginning and at the end of the trial in 10 patients on fenoprofen and in nine on aspirin.

Pain scores, duration of morning stiffness, grip strength, and walking times were analysed by Student's $t$ test. Because the initial values were not identical the differences between the initial values and the values at any particular time were used for the analysis. Student's $t$ test applied to paired data was used to identify significant changes within treatment groups-for example, the changes in serum uric acid. The numbers of joints showing swelling, tenderness, or limitation of movement and the numbers of patients showing particular side effects were analysed using the $\chi^{2}$ test. The change scales and the patients' opinions of treatment were analysed by the Mann-Whitney $U$ test.

\section{Results}

Three patients failed to complete the first trial; two found placebo ineffective and returned to their regular anti-inflammatory drug therapy, and one dropped out while on fenoprofen because of nausea and generalized aches and pains.

The results of the first trial are shown in table $\mathrm{I}$, with the results of $t$ tests applied to the group as a whole. At the end of the fenoprofen period there was a statistically highly significant reduction in pain, duration of morning stiffness, paracetamol consumption, grip strength, and articular index. There was no significant change in joint size or temperature. Results from the two centres were also analysed separately, and, apart from duration of morning stiffness, they gave similar results. In patients studied at St. Bartholomew's Hospital the reduction in duration of morning stiffness was small and not statistically significant. In both groups there was reduction in pain, paracetamol consumption, and articular index, with increase in grip strength; there was no significant reduction in joint size or

TABLE I-Mean Values in 57 Patients with Rheumatoid Arthritis after One Week on either Fenoprofen or Placebo. Differences Analysed by Student's $t$ Test applied to Paired Data

\begin{tabular}{|c|c|c|c|c|}
\hline & Fenoprofen & Placebo & $t$ Test & $\mathbf{P}$ \\
\hline Pain (Uniis) . & $7 \cdot 3$ & $11 \cdot 1$ & $5 \cdot 3$ & $<0.01$ \\
\hline $\begin{array}{l}\text { Duration of morning } \\
\text { stiffness (Min) } \\
\text { Paracetamol consu- }\end{array}$ & 61.8 & $106 \cdot 9$ & $3 \cdot 29$ & $<0.01$ \\
\hline $\begin{array}{l}\text { med (No. tabs.) } \\
\text { Joint size (mm) } \\
\text { Grip strength (mm Hg) } \\
\text { Articular index } \\
\text { Right knee }\end{array}$ & $\begin{array}{r}11 \cdot 6 \\
580.6 \\
599 \cdot 2 \\
9.0\end{array}$ & $\begin{array}{r}27 \cdot 1 \\
581 \cdot 1 \\
547 \cdot 4 \\
12 \cdot 8\end{array}$ & $\begin{array}{l}6 \cdot 73 \\
0 \cdot 62 \\
5 \cdot 35 \\
3 \cdot 91\end{array}$ & $\begin{array}{l}<0.01 \\
>0.1 \\
<0.01 \\
<0.01\end{array}$ \\
\hline $\begin{array}{l}\text { temperature* } \\
\text { Left knee temperature }\end{array}$ & $\begin{array}{l}-0.43 \\
-0.71\end{array}$ & $\begin{array}{l}-0.36 \\
-0.67\end{array}$ & $\begin{array}{l}0 \cdot 34 \\
0 \cdot 19\end{array}$ & $\begin{array}{l}>0 \cdot 1 \\
>0.1\end{array}$ \\
\hline
\end{tabular}

*Figures for knee temperature represent number of degrees Centigrade difference between the knee and the control area. Negative figures indicate that knee tempera-
ture was lower.

TABLE II-Mean Levels of Various Measures of Effectiveness during Trial

\begin{tabular}{|c|c|c|c|c|c|c|c|c|c|c|}
\hline Week No: & 0 & 1 & 2 & 3 & 4 & 8 & 12 & 16 & 20 & 24 \\
\hline $\begin{array}{l}\text { Pain (Units): } \\
\text { A. }\end{array}$ & $\begin{array}{l}10 \cdot 19 \\
13 \cdot 21\end{array}$ & $\begin{array}{l}7 \cdot 53 \\
8 \cdot 14^{*}\end{array}$ & $\begin{array}{l}8 \cdot 11 \\
8 \cdot 35^{*}\end{array}$ & $\begin{array}{l}7 \cdot 79 \\
9 \cdot 16 \dagger\end{array}$ & $\begin{array}{l}7 \cdot 83 \\
8 \cdot 48^{*}\end{array}$ & $\begin{array}{l}7.23 \\
7.91^{*}\end{array}$ & $\begin{array}{l}7 \cdot 38 \\
6.90 \dagger\end{array}$ & $\begin{array}{l}6.88 \\
7.57\end{array}$ & $\begin{array}{l}7 \cdot 88 \\
8 \cdot 80\end{array}$ & $\begin{array}{l}7 \cdot 53 \\
7 \cdot 76\end{array}$ \\
\hline $\begin{array}{l}\text { Morning stiffness }(\mathrm{Min}) \text { : } \\
\text { A. }\end{array}$ & $\begin{array}{l}124.03 \\
148.96\end{array}$ & $\begin{array}{l}52 \cdot 14 \\
58 \cdot 27\end{array}$ & $\begin{array}{l}48 \cdot 03 \\
46 \cdot 73\end{array}$ & $\begin{array}{l}37 \cdot 08 \\
43 \cdot 80\end{array}$ & $\begin{array}{l}48 \cdot 69 \\
46 \cdot 11\end{array}$ & $\begin{array}{l}38 \cdot 04 \\
37.91\end{array}$ & $\begin{array}{l}45 \cdot 24 \\
27 \cdot 86\end{array}$ & $\begin{array}{l}35 \cdot 29 \\
46 \cdot 33\end{array}$ & $\begin{array}{l}38 \cdot 23 \\
48 \cdot 40\end{array}$ & $\begin{array}{l}33.53 \\
60.24\end{array}$ \\
\hline $\begin{array}{l}\text { Grip strength }(\mathrm{mm} \mathrm{Hg}) \text { : } \\
\text { A. }\end{array}$ & $\begin{array}{l}286 \cdot 10 \\
266 \cdot 38\end{array}$ & $\begin{array}{l}341 \cdot 14 \dagger \\
290 \cdot 00\end{array}$ & $\begin{array}{l}338 \cdot 57 \\
284 \cdot 00\end{array}$ & $\begin{array}{l}349 \cdot 46 \\
291 \cdot 20\end{array}$ & $\begin{array}{l}347.83 \\
295.00\end{array}$ & $\begin{array}{l}305 \cdot 30 \\
294 \cdot 13\end{array}$ & $\begin{array}{l}315 \cdot 19 \\
290 \cdot 95\end{array}$ & $\begin{array}{l}332 \cdot 94 \\
277 \cdot 86\end{array}$ & $\begin{array}{l}319 \cdot 47 \\
280 \cdot 65\end{array}$ & $\begin{array}{l}316 \cdot 18 \\
283 \cdot 81\end{array}$ \\
\hline $\begin{array}{l}\text { Swelling (No. of joints): } \\
\text { A. } \\
\text { F. }\end{array}$ & $\begin{array}{l}6 \cdot 32 \\
6 \cdot 41\end{array}$ & $\begin{array}{l}6.25 \\
6.93\end{array}$ & $\begin{array}{l}6.50 \\
7.04\end{array}$ & $\begin{array}{l}6.75 \\
6.80\end{array}$ & $\begin{array}{l}5 \cdot 13 \\
5 \cdot 22\end{array}$ & $\begin{array}{l}5.04 \\
4.91\end{array}$ & $\begin{array}{l}3 \cdot 81 \\
4 \cdot 19\end{array}$ & $\begin{array}{l}3.53 \\
3.81\end{array}$ & $\begin{array}{l}3.35 \\
3.35\end{array}$ & $\begin{array}{l}3.35 \\
3.52\end{array}$ \\
\hline A. & $\begin{array}{r}8 \cdot 71 \\
10 \cdot 62\end{array}$ & $\begin{array}{l}7 \cdot 18 \\
9 \cdot 97\end{array}$ & $\begin{array}{r}7 \cdot 25 \\
10 \cdot 35\end{array}$ & $\begin{array}{l}7 \cdot 79 \\
9 \cdot 48\end{array}$ & $\begin{array}{l}7 \cdot 26 \\
8.63\end{array}$ & $\begin{array}{l}7 \cdot 39 \\
8 \cdot 22\end{array}$ & $\begin{array}{l}6.05 \\
8.19\end{array}$ & $\begin{array}{l}6 \cdot 06 \\
7 \cdot 48\end{array}$ & $\begin{array}{l}6 \cdot 76 \\
7.95\end{array}$ & $\begin{array}{l}6.53 \\
7.62\end{array}$ \\
\hline $\begin{array}{l}\text { Limitaion of movement } \\
\text { (No. of joints): A. }\end{array}$ & $\begin{array}{l}5 \cdot 26 \\
4 \cdot 79\end{array}$ & $\begin{array}{l}4.43 \\
4.59\end{array}$ & $\begin{array}{l}4 \cdot 75 \\
4 \cdot 54\end{array}$ & $\begin{array}{l}4.50 \\
4 \cdot 32\end{array}$ & $\begin{array}{l}3.83 \\
3.96\end{array}$ & $\begin{array}{l}4 \cdot 13 \\
2 \cdot 91\end{array}$ & $\begin{array}{l}3 \cdot 76 \\
3.38\end{array}$ & $\begin{array}{l}2 \cdot 29 \\
2 \cdot 14\end{array}$ & $\begin{array}{l}2 \cdot 94 \\
2 \cdot 40\end{array}$ & $\begin{array}{l}2 \cdot 65 \\
2 \cdot 19\end{array}$ \\
\hline $\begin{array}{l}\text { Walking time (Sec.): } \\
\text { A. } \\
\text { F. }\end{array}$ & $\begin{array}{l}8 \cdot 29 \\
9 \cdot 07\end{array}$ & $\begin{array}{l}8.03 \\
8.29\end{array}$ & $\begin{array}{l}7.68 \\
7.92\end{array}$ & $\begin{array}{l}7 \cdot 25 \\
7 \cdot 58\end{array}$ & $\begin{array}{l}7 \cdot 17 \\
7.89\end{array}$ & $\begin{array}{l}8 \cdot 26 \\
7 \cdot 15\end{array}$ & $\begin{array}{l}7 \cdot 26 \\
7 \cdot 13\end{array}$ & $\begin{array}{l}6.97 \\
6.90\end{array}$ & $\begin{array}{l}7 \cdot 23 \\
7 \cdot 50\end{array}$ & $\begin{array}{l}6.88 \\
7.02\end{array}$ \\
\hline $\begin{array}{l}\text { No. of patients: } \\
\text { A. } \\
\text { F. }\end{array}$ & $\begin{array}{l}31 \\
29\end{array}$ & $\begin{array}{l}28 \\
29\end{array}$ & $\begin{array}{l}28 \\
26\end{array}$ & $\begin{array}{l}24 \\
25\end{array}$ & $\begin{array}{l}23 \\
27\end{array}$ & $\begin{array}{l}23 \\
23\end{array}$ & $\begin{array}{l}21 \\
21\end{array}$ & $\begin{array}{l}17 \\
21\end{array}$ & $\begin{array}{l}17 \\
20\end{array}$ & $\begin{array}{l}17 \\
21\end{array}$ \\
\hline $\begin{array}{l}\text { Joint size (change) } \ddagger \text { : } \\
\text { A. } \\
\text { F. }\end{array}$ & & & & & $\begin{array}{l}4.50 \\
3.40\end{array}$ & $\begin{array}{l}6 \cdot 78 \\
4.33\end{array}$ & $\begin{array}{l}8 \cdot 78 \\
3 \cdot 60\end{array}$ & $\begin{array}{r}15 \cdot 25 \\
8 \cdot 27\end{array}$ & $\begin{array}{l}9.63 \\
7.09\end{array}$ & $\begin{array}{r}13.50 \\
6.73\end{array}$ \\
\hline $\begin{array}{l}\text { No. of patients: } \\
\text { A. } \\
\text { F. }\end{array}$ & & & & & $\begin{array}{l}11 \\
15\end{array}$ & $\begin{array}{r}9 \\
12\end{array}$ & $\begin{array}{r}9 \\
10\end{array}$ & $\begin{array}{r}8 \\
11\end{array}$ & $\begin{array}{r}8 \\
11\end{array}$ & $\begin{array}{r}8 \\
11\end{array}$ \\
\hline
\end{tabular}

+Statistically highly significant $(P<0.01)$

- Statistically significant $(P<0.05)$.

\pm Figures for ioint size represent mean changes from start of treatment which at all times on both drugs were improved.

A Figures for $=$ Aspinin. $\mathrm{F}=$ Fenoprofen.
. 
temperature. Twenty-five patients preferred fenoprofen, two preferred placebo, and one had no preference. The difference is statistically highly significant $(P<0.01)$.

The results of the second trial are shown in table II. There was a greater reduction in pain on fenoprofen than on aspirin which was statistically significant between the first and 12th weeks and thereafter of borderline significance; this is explained by the higher initial pain scores on fenoprofen. There was a highly significant correlation in the group as a whole between pain relief and initial pain score $(r=0.55, \mathrm{P}<0.01)$. There was a significantly greater increase in grip strength on aspirin at the end of the first week only. The patient's opinion of the medication showed a statistically significant difference in favour of fenoprofen in the second week $(P<0.05)$; there was a trend favouring fenoprofen in the first week but this did not achieve statistical significance $(0 \cdot 1>P>0.05)$. After the second week there was no significant difference. Changes from the previous visit showed a statistically significant difference in favour of fenoprofen in the first week but not thereafter. Other measurements showed no statistically significant difference between the effects of the two drugs.

Relief of pain was greatest in the first week of the trial on both drugs; there was no further improvement after this time.

Eight patients on fenoprofen and 14 on aspirin were withdrawn before the end of the trial; this difference is not statistically significant $\left(\chi^{2}=1.99, P>0 \cdot 1\right)$. Reasons for withdrawal and the week of withdrawal in the case of fenoprofen were: rash (1); lack of effect (1); lack of effect (4); lack of effect (20); lack of effect, tinnitus, and indigestion (4); lack of effect, headache, and dizziness (4); death from septicaemia and renal failure (12); and, unrelated domestic reasons (8). The reasons for withdrawal of asiprin and the week of withdrawal were: lack of effect (3); lack of effect (12); lack of effect and tinnitus (2); lack of effect and tinnitus (8); lack of effect, headache, and malaise (4); dizziness (1); nausea, dizziness, and tinnitus (2); tinnitus (3); thrombocytopenia and gastrointestinal upset (3); tinnitus and indigestion (8); vomiting and tinnitus (12); nausea, vomiting, and abdominal pain (16); indigestion (16); and death from myocardial infarction (1). Withdrawals from lack of effect were equal in the two groups, but there was an excess of tinnitus and gastrointestinal disturbance in the aspirin group. In the patient who died while taking fenoprofen necropsy showed bilateral suppurative pyelonephritis with papillary necrosis; it was the opinion of those involved in the case that infection was the basic cause of the renal lesion and that it was unlikely to be related to the treatment.

The total incidence of side effects is shown in fig. 1 . Side effect scores represent the total score for all patients at one assessment time, severe side effects scoring 3 , moderate 2 , and mild 1 , expressed as a percentage of the number of patients remaining

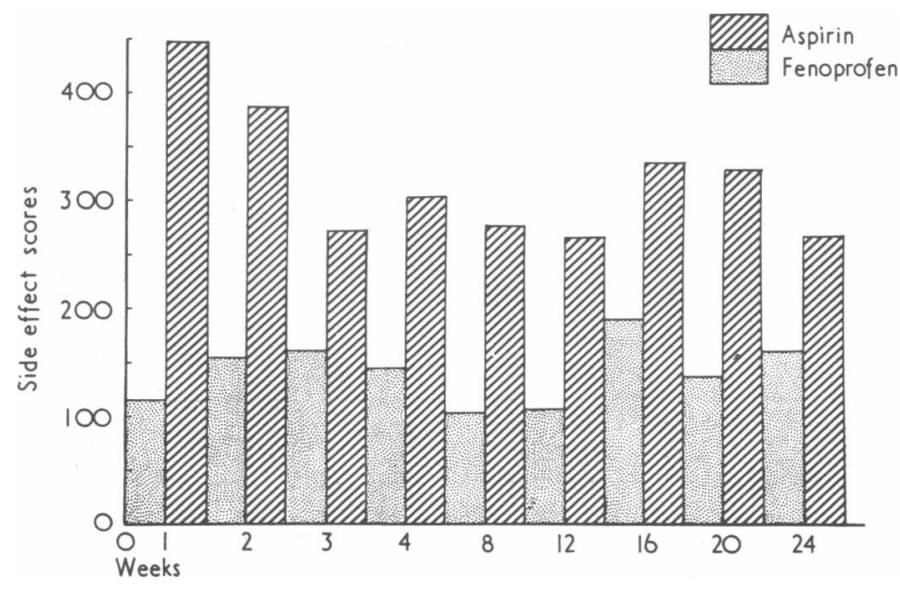

FIG. 1-Side effect scores. These represent total for all patients at a particular time, a mild side effect scoring 1 , moderate 2 , and severe 3 . in the trial. A score of $100 \%$ would thus represent on average one mild side effect per patient. It is clear that the incidence of side effects is very much higher on aspirin; the falling incidence on aspirin with progress of the trial is presumably due partly to withdrawal of patients with severe side effects and partly to reduction in dosage. No relevant ophthalmic abnormalities were detected.

The higher incidence of side effects on aspirin is due to an excess of two groups of symptoms, related to the auditory nerve and the gastrointestinal tract. The relative incidence of these side effects is shown in figs. 2 and 3. In the first week of the trial $66 \%$ of patients on aspirin complained of tinnitus or deafness and the difference between the incidence of these side effects on aspirin compared with fenoprofen was statistically highly significant (table III). Auditory side effects were common throughout the trial; the incidence of tinnitus and deafness on aspirin in the 24th week was still $41 \%$ and the difference between the two drugs remained highly significant $\left(\chi^{2}=7 \cdot 50\right.$, $P<0 \cdot 01$ ).

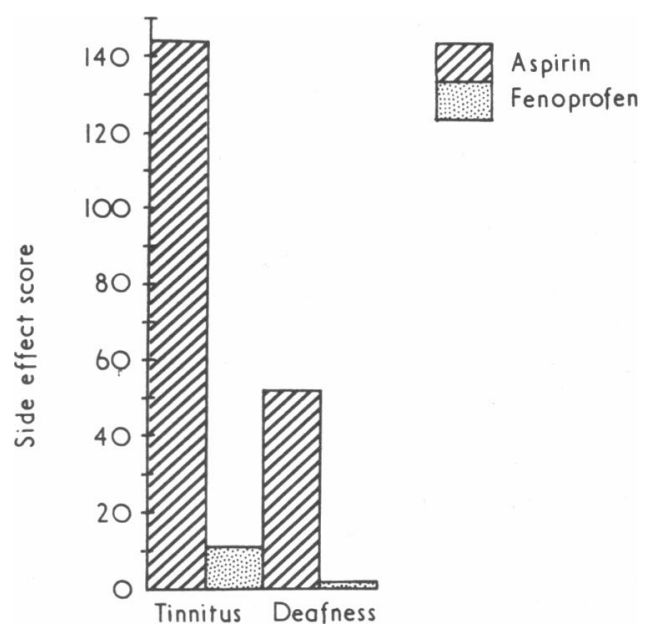

FIG. 2-Auditory side effect scores occurring throughout trial.

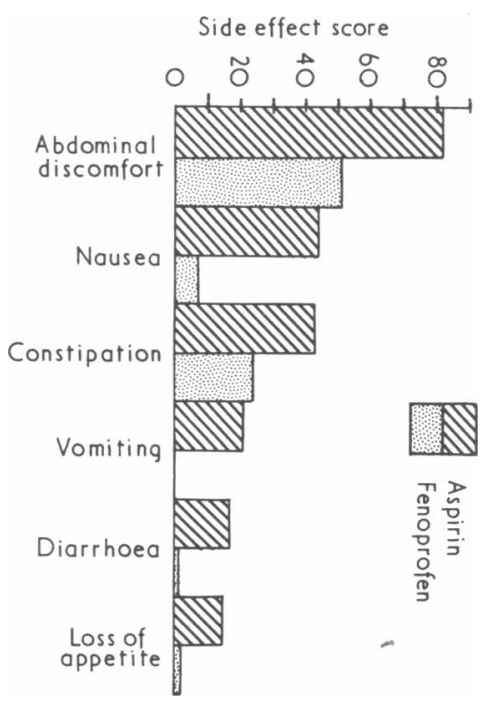

FIG. 3-Gastrointestinal side effect score occurring throughout trial.

The incidence of gastrointestinal side effects was significantly greater on aspirin than on fenoprofen in the first (table IV), second, and third weeks of the trial, but therafter the differences 
were smaller and not statistically significant; by the end of the trial there was very little difference between the two drugs.

There was no statistically significant difference between the incidence in aspirin and fenoprofen of any other side effect or group of side effects, either in any one week or during the course of the trial.

TABLE III-Numbers of Patients with Tinnitus or Deafness in First Week of Trial

\begin{tabular}{|c|c|c|c|c|c|}
\hline & & & \multicolumn{3}{|c|}{ Tinnitus/Deafness } \\
\hline & & & Present & Absent & Total \\
\hline $\begin{array}{l}\text { Aspirin .. } \\
\text { Fenoprofen }\end{array}$ & $\therefore$ & $\begin{array}{ll}. & . \\
. & .\end{array}$ & $\begin{array}{r}19 \\
1\end{array}$ & $\begin{array}{l}10 \\
28\end{array}$ & $\begin{array}{l}29 \\
29\end{array}$ \\
\hline \multicolumn{3}{|c|}{ Total } & 20 & 38 & 58 \\
\hline
\end{tabular}

$\chi^{2}=24 \cdot 7, P<0.01$.

TABLE IV-Numbers of Patients with Nausea, Vomiting, Abdominal Discomfort, Diarrhoea, Constipation, or Anorexia in First Week of Trial

\begin{tabular}{|c|c|c|c|c|c|}
\hline & & & \multicolumn{3}{|c|}{ Gastrointestinal Side Effects } \\
\hline & & & Present & Absent & Total \\
\hline $\begin{array}{l}\text { Aspirin } \ldots \\
\text { Fenoprofen }\end{array}$ & $\therefore$ & $\therefore$ & $\begin{array}{r}14 \\
6\end{array}$ & $\begin{array}{l}15 \\
23\end{array}$ & $\begin{array}{l}29 \\
29\end{array}$ \\
\hline \multicolumn{3}{|c|}{ Total } & 20 & 38 & 58 \\
\hline
\end{tabular}

$\chi^{2}=4 \cdot 86, P<0.05$

\section{CHANGES IN HAEMATOLOGICAL AND BIOCHEMICAL MEASUREMENTS}

Slight falls in haemoglobin levels, white blood counts, and platelet counts were seen in both groups, but no patient in either group became seriously anaemic, neutropenic, or thrombocytopenic. The E.S.R. showed no change in either group. Slight prolongation of the prothrombin time was seen in 17 patients on aspirin and in 10 on fenoprofen. In no case were relevant symptoms noted at the time of any haematological abnormality.

Altogether $15 \%$ of patients had raised blood urea levels at the start of the trial. Apart from these, nine on aspirin and six on fenoprofen had slightly raised levels of blood urea during the trial, with maximum levels of 59 and $63 \mathrm{mg} / 100 \mathrm{ml}$. Only three patients on aspirin and two on fenoprofen had blood urea levels greater than $45 \mathrm{mg} / 100 \mathrm{ml}$. Uric acid levels fell in both groups; on aspirin by a mean of $1.9 \mathrm{mg} / 100 \mathrm{ml}$ in the first month (statistically highly significant, $t=5.97, \mathrm{P}<0.01$ ) and by 1 $\mathrm{mg} / 100 \mathrm{ml}$ on fenoprofen (statistically significant, $t=2 \cdot 16$, $P<0.05)$. The uricosuric action of aspirin was significantly greater than that of fenoprofen $(t=3.42, \mathrm{P}<0.01)$. Raised levels of serum bilirubin were not seen in either group. Altogether $38 \%$ had raised alkaline phosphatase levels at the start of the trial. Apart from these, one patient on aspirin and one on fenoprofen had slightly raised levels during the trial. SGOT levels were slightly raised in four patients on aspirin and four on fenoprofen. Raised levels of serum glucose were not seen in any patient. Occasional minor abnormalities of serum cholesterol, calcium, phosphates, total protein, and albumin levels were seen in both groups. No significant changes in Rose-Waaler and latex tests were found.

\section{DOSAGE AND BLOOD LEVELS}

The mean doses of aspirin and fenoprofen taken are shown in table $\mathrm{V}$. The dose of aspirin fell rapidly from the starting dose of $6 \mathrm{~g}$ daily and the average remained at about $4 \mathrm{~g}$ daily during the trial. Fenoprofen was continued at the starting dose of $2 \cdot 4 \mathrm{~g}$ daily throughout the trial.
Mean blood levels of aspirin and fenoprofen are shown in table VI. These figures are based only on patients who had taken their last dose within six hours of blood being taken.

Blood levels showed a high degree of co-operation from the patients. Significant blood levels of only the appropriate drugfor example, significant fenoprofen level and no aspirin-were found on $94.6 \%$ of all occasions when assessments were made and blood levels checked; $88.4 \%$ of patients had appropriate blood levels at all assessments during the trial. One patient had insignificant fenoprofen levels on one occasion and another had insignificant aspirin levels on two occasions; five patients taking fenoprofen had significant aspirin levels on seven occasions, one of $20.6 \mathrm{mg} / 100 \mathrm{ml}$, the remainder were between 2.4 and 6.4 $\mathrm{mg} / 100 \mathrm{ml}$.

TABLE V-Mean Doses of Fenoprofen and Aspirin

\begin{tabular}{l|l|l|l|l|l|l}
\hline Week No: & 4 & 8 & 12 & 16 & 20 & 24 \\
\hline Fenoprofen (g/day) & $2 \cdot 2$ & $2 \cdot 5$ & $2 \cdot 5$ & $2 \cdot 5$ & $2 \cdot 4$ & $2 \cdot 4$ \\
No. of patients & 27 & 23 & 21 & 21 & 20 & 21 \\
Aspirin (g/day) & $4 \cdot 6$ & $4 \cdot 6$ & $4 \cdot 5$ & $4 \cdot 2$ & $4 \cdot 4$ & 3.9 \\
No. of patients & 23 & 23 & 21 & 17 & 17 & 17 \\
\hline
\end{tabular}

TABLE VI-Mean Blood Levels of Aspirin and Fenoprofen

\begin{tabular}{|c|c|c|c|c|c|c|}
\hline Week No: & 4 & 8 & 12 & 16 & 20 & 24 \\
\hline $\begin{array}{l}\text { Aspirin }(\mathrm{mg} / 100 \mathrm{ml}) \\
\text { No. of patients } \\
\text { Fenoprofen }(\mu \mathrm{g} / \mathrm{ml}) \\
\text { No. of patients }\end{array}$ & $\begin{array}{c}19 \cdot 0 \\
21 \\
39 \cdot 9 \\
23\end{array}$ & $\begin{array}{c}17 \cdot 5 \\
18 \\
41 \cdot 6 \\
19\end{array}$ & $\begin{array}{r}17 \cdot 3 \\
7 \\
68 \cdot 7 \\
7\end{array}$ & $\begin{array}{c}14 \cdot 8 \\
12 \\
59 \cdot 7 \\
17\end{array}$ & $\begin{array}{r}20 \cdot 0 \\
8 \\
48 \cdot 5 \\
8\end{array}$ & $\begin{array}{c}18 \cdot 2 \\
12 \\
43 \cdot 6 \\
16\end{array}$ \\
\hline
\end{tabular}

\section{Discussion}

Drugs with anti-inflammatory activity have proved to be particularly useful in controlling the symptoms of rheumatoid arthritis. Such drugs, exemplified by aspirin in high doses, indomethacin, and phenylbutazone, have in common the reduction of proximal interphalangeal joint size (Boardman and Hart, 1967) and also the potential to produce gastric toxicity of various types. It now seems justifiable to place in a separate category a group of drugs, exemplified by ibuprofen, which have demonstrable analgesic properties in rheumatoid arthritis, do not reduce joint size, and show much less gastric toxicity (Huskisson et al., 1971). Our evidence suggests that fenoprofen is a compound of this type. These drugs have anti-inflammatory properties in animals, and it is argued that methods of measurement of inflammation are too crude to show their effects in man. Until further evidence is available it is probably wise to refer to these drugs as having analgesic and minor anti-inflammatory properties, since they have more in common with the major anti-inflammatroy drugs than with the simple analgesics. It is likely that compounds of this type will be particularly useful when the major anti-inflammatory drugs cannot be tolerated and in less severe cases of rheumatoid arthritis and minor musculoskeletal disorders in which powerful anti-inflammatroy effect is not required and accompanying toxicity is not justified.

In this study fenoprofen proved as effective as aspirin in relieving the pain of rheumatoid arthritis. Fenoprofen was well tolerated and no major or important side effects were attributable to it. A trial such as this would detect only the more common side effects of a drug, and experience with much larger numbers will be required before the safety of fenoprofen is confirmed. If is possible to conclude from this study that two groups of side effects, gastrointestinal and auditory, are significantly less common on fenoprofen than on aspirin. Since side effects occur even with placebo therapy it is not possible to decide whether the side effects which were reported by patients taking fenoprofen were due to the drug.

The high incidence of side effects due to aspirin therapy is 
noteworthy, especially since this drug has for so long been regarded as the treatment of choice in rheumatoid arthritis. Almost half of the patients failed to continue aspirin therapy for six months and the remainder were able to take on average only $4 \mathrm{~g}$ daily. Even with this dose almost half of the patients continued to have tinnitus or deafness. By contrast gastrointestinal side effects did not persist throughout the six months of the trial, probably because patients could not tolerate such side effects and either dropped out or reduced the dose.

We are indebted to Dr. Enid Taylor and Mr. I. Duiguid, who carried out the ophthalmic examinations, and to Dista Products Ltd., for supply of materials and for their co-operation in the study.

\section{References} Boardman, P. L., and Hart, F. D. (1967). British Medical fournal, 4, 264.
Chernish, S. M., Rubin, A., Rodda, B. E., Ridolfo, A. S., and Gruber, C. M. (1972). Clinical Pharmacology and Therapeutics, 14, 226.

Gruber, C. M., and Collins, T. (1972). Fournal of Medicine, 3, 242

Huskisson, E. C., Hart, F. D., Shenfield, G. M., and Taylor, R. T. (1971) Practitioner, 207, 639 .

Nickander, R. C., Kroay, R. J., and Marshall, W. S. (1971). Federation Proceedings, 30, 563 .

Ridolfo, A. S., Rubin, A., Crabtree, R. E., and Gruber, C. M. (1973). Clinical Pharmacology and Therapeutics, 14, 226.

Ritchie, D. M., et al. (1968). Quarterly fournal of Medicine, 37, 393.

Rubin, A., et al. (1972). Fournal of Pharmacology and Experimental Therapeutics, 13, 151 .

Sunshine, A., and Laska, E. (1971). Clinical Pharmacology and Therapeutics, 12,302 .

\title{
Penicillamine in Rheumatoid Disease: A Long-term Study
}

\author{
ALBERT T. DAY, JOHN R. GOLDING, PETER N. LEE, ANN D. BUTTERWORTH
}

British Medical fournal, 1974, 1, 180-183

\section{Summary}

Eighty-five patients with rheumatoid disease were treated with penicillamine, and 69 completed more than one year's treatment. The main reason for discontinuing penicillamine in the 16 patients who withdrew was adverse reaction. The number of adverse reactions, however, declined when patients were given lower maintenance doses of penicillamine. In those who tolerated the drug the results of treatment were good. To prevent side effects the drug should be introduced gradually and maintenance doses should be the lowest which produce a satisfactory response. Urine should be monitored for protein and blood for changes in platelet and white cell counts at frequent intervals throughout treatment.

\section{Introduction}

We began a study of penicillamine therapy in rheumatoid disease in 1967, encouraged by reports from the U.S.A. (Jaffe, 1963). When we found that our preliminary results were in general agreement with those of Jaffe (Golding et al., 1968; 1970) a multicentre controlled trial was conducted (Multicentre Trial Group, 1973). We here report on the further progress of the original group of patients, some of whom have now completed five years of treatment. This is the largest recorded series of patients with the longest period of follow-up, and from it we have concluded that smaller doses of penicillamine than are usually advocated are often effective and cause fewer adverse reactions-a matter of some consequence now that the drug is being more widely prescribed.

\section{Patients and Methods}

All the patients admitted to the study had "definite" or

Royal Bath Hospital, Harrogate, Yorkshire

ALBERT T. DAY, M.B., M.R.c.G.P., General Practitioner, Clinical and

Research Assistant
JOHN R. GOLDING, D.M., M.R.C.P., Consultant Physician

PETER N. LEE, M.A., Consultant Statistician

ANN D. BUTTERWORTH, B.SC., Consultant Statistician "classical" rheumatoid arthritis according to American Rheumatism Association criteria and had had laboratory and clinical evidence of active disease for at least a year. All were attending the Royal Bath Hospital, Harrogate. Their progress was assessed monthly by the following indices: (1) erythrocyte sedimentation rate (Westergren); (2) haemoglobin; (3) sheep cell agglutination test; (4) latex fixation test; (5) duration of morning stiffness (hours); (6) weight; and (7) an observer assessment of the patient's improvement during the previous year, expressed as an integer in a range of -4 to +4 (no change $=0$ ).

Dosage.-Penicillamine was given as $150-\mathrm{mg}$ capsules of penicillamine hydrochloride or as $250-\mathrm{mg}$ tablets of penicillamine base (Distamine). An initial four capsules daily was rapidly increased to 16 (or eight tablets). The incidence of side effects, both major and minor, was such that we later adopted Jaffe's (1968) recommendation of beginning with not more than two capsules and slowly increasing the dose. More recently the starting dose has been $150 \mathrm{mg}$ daily and the maintenance dose has been kept as low as the disease response allowed-often a dose of $300-600 \mathrm{mg}$ is enough. The use of this low-dose regimen has apparently eliminated the serious blood changes seen previously.

Concomitant Therapy.-All of the patients were receiving anti-inflammatory drugs at the beginning of the study and many were on corticosteroid therapy. The latter was slowly withdrawn to conform to a maximum daily dose of $7.5 \mathrm{mg}$, then further reductions were made as the disease improved. Short courses of prednisolone were given for any acute flare-up. The amount of anti-inflammatory agent given varied, and phenylbutazone was withdrawn because of possible confusion in the interpretation of side effects. Indomethacin, $50-75 \mathrm{mg}$ nightly, was given to overcome morning stiffness but was withdrawn when possible. Intra-articular injections and physiotherapy were prescribed at the clinician's discretion. Copper sulphate solution $(0.1 \%)$ $5 \mathrm{ml}$ was given daily. Pyridoxine was not given.

\section{Results}

Between January 1967 and May 197385 patients had been given penicillamine and 69 had taken it for a year or more. The other 16 patients failed to complete one year's treatment for various reasons (table I). Of the 69 who took the drug for a year or more 24 took it for one full year, 14 for two years, 14 for three years, 14 for four years, and three for five years. Forty-five of the 69 patients are still taking penicillamine; the remaining 24 discontinued it for various reasons (table II). 